\title{
Over-yielding in temperate silvopastures: a meta-analysis
}

\author{
Gabriel J. Pent $\mathbb{D}$
}

Received: 12 November 2019/Accepted: 16 April 2020/Published online: 27 April 2020

(C) The Author(s) 2020

\begin{abstract}
Over-yielding in an intercropping system occurs when the productivity of the intercrop exceeds the overall productivity of the systems managed in segregation. The objective of this systematic review was to calculate the over-yielding of silvopastures compared to open pastures and forests, timber plantations, or orchards managed separately. A literature search was completed for comparisons of the productivity of these practices in temperate regions. Data collected from these studies included mean yields of timber or non-timber forest products, forages, and livestock, as well as the characteristics of the study site. Silvopasture practices improve the productivity of land typically managed separately for pasture or trees by $42-55 \%$, depending on whether the productivity of the pastures is measured by livestock or forage output, respectively. In most cases, overyielding occurred despite a reduction in individual forage, livestock, or tree productivity in the silvopastures. Calculating confidence intervals around these means was not feasible because standard errors were largely not reported or available. Some assumptions were made about the actual productivity of timber or non-timber forest products. This work illustrates the
\end{abstract}

G. J. Pent $(\bowtie)$

Shenandoah Valley Agricultural Research and Extension Center, Virginia Polytechnic Institute and State University, 128 McCormick Farm Circle, Raphine,

VA, USA

e-mail: gpent@vt.edu significant level of over-yielding that may be achieved by integrating trees, forages, and livestock into a single production system.

Keywords Silvopasture $\cdot$ Yield · Production · Forage $\cdot$ Livestock $\cdot$ Tree

\section{Introduction}

Integrating trees with pastures for livestock is an intensive practice (Sharrow et al. 2009). The manager of such a combination must protect trees from potential damage by livestock, but also periodically prune or thin the trees to maintain enough forage production in the understory to sustain a herd or flock of animals (Robinson and Clason 2000; Lehmkuhler et al. 2003). When water is scarce during droughts, established trees may vigorously compete with the forages for water resources (Karki and Goodman 2015), although this may not result in a reduction in forage growth under some conditions (DeBruyne et al. 2011). In a similar way, competition for light may reduce forage growth underneath trees when the days are short or when the sky is overcast for prolonged periods of time (Feldhake et al. 2005). To sustain longterm forage production and persistence, the manager must alter the livestock stocking management typically employed in open pastures to apply appropriately 
to the silvopastures (Belesky 2005a, b; Neel and Belesky 2017). Besides managing competitive interactions between the components of these complex systems, the manager must be well versed in the care and production of two different crops-forages and trees-in addition to livestock. Managing the complexity of silvopastures is a challenging task for the land manager.

Nevertheless, the complexity of silvopastures also presents an opportunity for greater land productivity. Within an intercropping system-where two or more crops are managed in the same space at the same time-there are a number of interactions occurring between the components of the community. These interactions may have negative implications for one or more members of the community. The plants within a silvopasture-forages and trees-will compete directly for available resources, such as light and soil moisture and nutrients. Competitive interactions are often perceived as a primary hindrance to the success of a silvopasture system (Workman et al. 2003). However, interactions may also have some beneficial effects on one or more members of the community. One example of a common facilitative effect in a silvopasture is the cooling effect of trees on the body temperatures of grazing livestock during the summertime (Pent et al. 2018). Another example would be the contribution of nitrogen from nitrogen-fixing black locust trees (Robinia pseudoacacia L.) to forage plants through decomposing leaf litter (Feldhake et al. 2008). A common goal for the silvopasture manager is to manage for facilitative interactions over competitive interactions.

Greater system productivity may also be realized through improvements in resource use efficiency. Mixtures of different plants or animals may utilize resources in different spaces, at different times, and through divergent mechanisms, a phenomenon known as niche partitioning. Tree and forage species that can utilize resources in different zones within the soil or at different seasons of the year are often good candidates for a silvopasture system (Schroth 1998). Through facilitative interactions and improved resource use efficiency, intercropping practices may be more productive per land unit area than practices where crops are grown separately. The potential for greater productivity in silvopastures has been cited as a compelling reason to merge pasture-based livestock production with silviculture (Sharrow et al. 1996).
The Land Equivalency Ratio (LER) is a mathematical tool for understanding the value of intercropping practices relative to production practices that are managed in segregation (Vandermeer 1981). By calculating the LER of a silvopasture, one may determine how productive a silvopasture is relative to open pastures and forests managed separately. The LER is calculated by the summation of two ratios: A. The productivity of forages or livestock in the silvopasture to the productivity of forages or livestock in a comparable open pasture; and $\mathrm{B}$. The ratio of productivity of timber or tree crops in the silvopasture to the productivity of timber or tree crops in a comparable forest, woodlot, or orchard. Only the units of measurement within each ratio must be equivalent, allowing for a comparison of multiple goods that are typically measured in distinct ways.

While some attempts have been made to quantify and compare LERs within single studies, there is no comprehensive meta-analysis of the LER of silvopasture practices as compared to segregated production practices. Intercrops generally have been cited to be more productive than crops managed separately (Vandermeer 1981; Hiebsch and McCollum 1987). Knowing by how much more and under what conditions silvopastures are more productive is valuable information for the land manager interested in establishing these intensive systems. The objective of this systematic review is to summarize the LERs of silvopastures in temperate regions. Studies included in this review will provide comparisons of productivity in silvopastures to productivity of similar pastures and forests, timber plantations, or orchards managed separately.

\section{Materials and methods}

\section{Data collection}

A systematic review allows for the synthesis of the results from a number of studies through an objective process. The PRISMA methodology and flow were followed for this review (Moher et al. 2009). For the purposes of this review, silvopasture was defined as a system where, "Trees and livestock are combined with improved pasture plants to form a carefully designed system that is an integration of intensive animal husbandry, silviculture, and forage agronomy 
practices" (Sharrow et al. 2009). Forest grazing and similar rangeland-management practices did not meet these criteria and thus were excluded from the scope of this review. The objective of this review was to compare the productivity of forages and livestock in open pastures and timber or non-timber forest products in forests, timber plantations, or orchards to the productivity of those same components in comparable silvopastures. Studies included in this review must have reported productivity data of forages or livestock or both in silvopastures and open pastures. Studies must also have reported productivity data of trees in silvopastures or conventional silvicultural systems. If true comparisons to conventional pasture or silvicultural systems were not provided within each study, studies were included if the authors provided a reasonable opportunity through site descriptions to assume certain levels of production in the conventional systems or alternative manuscripts provided the missing data from each study. This review only compared productivity in temperate silvopastures due to large differences in the definitions and characteristics of temperate versus tropical agroforestry systems.

A comprehensive search for relevant articles was completed using CAB Direct (Centre for Agriculture and Bioscience International, Oxfordshire, United Kingdom, 1920-2019). The literature search was completed in March 2019. The keywords used in this systematic search included terms for describing a silvopasture, terms for describing agricultural or forestry production, and terms for livestock or forage production (Table 1). Some exclusionary terms were also included to exclude a large number of studies from tropical regions, which were beyond the scope of this review. This included species of plants that are frequently found in tropical silvopasture systems, but not in temperate silvopasture systems.

Studies were screened through a stepwise process. After identification through the database search, titles, abstracts, and keywords were analyzed to determine if each study met the criteria for this review. Only peerreviewed journal articles or book chapters written in English were selected for further analysis. If they appeared to meet the criteria, the full text of each article was reviewed for eligibility. An additional six records of a recent publication date that had not be identified through the search, but that had been identified through previous knowledge of silvopasture research were included in the screened records.

Production data were extracted from tables if provided in the selected articles. If data were only available from figures, they were extracted with the GetData Graph Digitizer (GetData Graph Digitizer, version 2.26.0.20, Fedorov S, Russia). Information recorded from each of these comparisons included country where the study site was located, tree species, predominant forage species, and livestock species, if applicable. Mean productivity values of pasture or silvicultural production metrics were collected and recorded from each study. Mean standard errors were also collected if available and reported in the text, tables, or figures. Reported standard deviations (SD) were converted to standard error (SE) by:

$\mathrm{SE}=\mathrm{SD} / \sqrt{ }(\mathrm{n})$,

where $\mathrm{n}$ is the sample size. Reported LSD values ( $\alpha=0.05$ ) were converted to SE by dividing the LSD by three.

Metrics related to tree productivity varied widely across articles, including measures related to tree height or diameter, basal area per hectare, trees per hectare, and biomass yield per hectare. Metrics related to forage production were reported or converted to a dry matter basis yield per hectare or a percent of the productivity of a conventional open pasture. Metrics related to animal production were reported in some cases as both individual animal yield, including both weight gains for cattle or sheep and fleece weights for sheep, and stocking rates or carrying capacities per
Table 1 Terms used in systematic search of database

\begin{tabular}{lll}
\hline Search string & Statement & Search terms \\
\hline 1 & Includes & Silvopasture OR silvopastoral \\
2 & Includes & Production OR productivity OR yield \\
3 & Includes & Forage OR livestock OR animal OR cattle OR sheep OR goat \\
4 & Excludes & Tropical OR tropic \\
5 & Excludes & Brachiaria OR leucaena OR eucalyptus \\
\hline
\end{tabular}


year of both cattle or sheep. All comparisons of a single product within studies were converted to the same metric of productivity. However, because total system productivity is compared between products and articles on a ratio basis (no units), the unique metrics utilized within each individual study have no influence on the overall assessments.

As a result of varying quality in control treatments available to compare to silvopastures in each record, a brief description of how or which controls were utilized was included for each study, as well as the assumptions that were made to make these comparisons.

Data analysis

A comparison of LERs was made to determine the system productivity of silvopastures compared to open pastures or forests managed separately. The production of each component (tree, forage, and/or livestock) within a silvopasture was compared to the production of that same component either within the open pasture or forest comparisons using the ratio of the former to the latter. These ratios were summed to calculate a separate LER for either forage or animal production or both, if applicable:

$$
\begin{aligned}
& \text { LER }_{\text {Forage }}= \text { Tree yield }_{\mathrm{SP}} / \text { Tree yield }_{\mathrm{F}} \\
&+ \text { Forage yield }_{\mathrm{SP}} / \text { Forage yield }_{\mathrm{P}}, \\
& \mathrm{LER}_{\text {animal }}= \text { Tree yield } \\
&+ \text { Animal yield }_{\mathrm{SP}} / \text { Tree yield }_{\mathrm{F}} \\
& \text { Animal yield } \\
& \mathrm{P}
\end{aligned}
$$

where $\mathrm{F}$ signifies productivity in a forest, timber plantation, or orchard comparison, $\mathrm{P}$ signifies productivity in an open pasture comparison, and SP signifies productivity in the silvopasture treatment.

\section{Results}

Study selection process

A total of 862 records were identified through this search plus the additional six articles included based on prior knowledge of the literature (Fig. 1). These additional articles were recently published, which may be why they were not identified in the initial search. Most of the records that were identified in the initial search were excluded because they did not report actual production numbers from silvopastures or because they featured studies completed in tropical regions. Thirty-eight full-text articles were assessed for eligibility. Twenty-two articles were included in the quantitative synthesis. Of the full-text articles assessed for eligibility, two were excluded because they did not include an open pasture control (Oswald et al. 2017; Pearson and Baldwin 1993), a forest or timber plantation control (Silva-Pando et al. 2002), or both (Debruyne et al. 2011; Ares et al. 2006; LopezDiaz et al. 2009; Morris and Clason 1997; Perry et al. 2009; Devkota et al. 2009; Fernandez-Nunez et al. 2014; Folkard et al. 2012; Houx et al. 2012; Lehmkuhler et al. 1999; Lewis 1989; Lindgren and Sullivan 2014; Lindgren et al. 2017) and no reasonable assumptions about the productivity of such controls were provided by the authors.

Characteristics and assumptions of selected records

The general approach was to standardize metrics reported by the selected studies. This required some unit conversion as well as some assumptions described as follows for each study.

In Anderson and Moore (1987), the productivity of trees in the medium and light density plantings were both compared to the high density planting, which was included as the forest control. Animal productivity was converted to yearly fleece weight per hectare using year-seven fleece weights and the mean yearly carrying capacity of the pastures.

Angima et al. (2010) compared forage production under two types of thinned Douglas-fir (Pseudotsuga menziesii [Mirb.] Franco) forests. These forests had been thinned using a conventional pre-commercial thinning procedure, and thus trees per acre was considered equivalent between the forest and silvopasture alternatives. Forage yield was determined by the mean yield reported at three locations within each silvopasture treatment.

Bambo et al. (2009a, b) compared open pastures to two types of silvopastures in which either several tree rows were removed to establish forages in 15.24-m alleyways (double-row configuration) or every 4th row was thinned along with additional selection thinning (random configuration). The resulting silvopastures contained 225 trees $\mathrm{ha}^{-1}$ while a nearby 


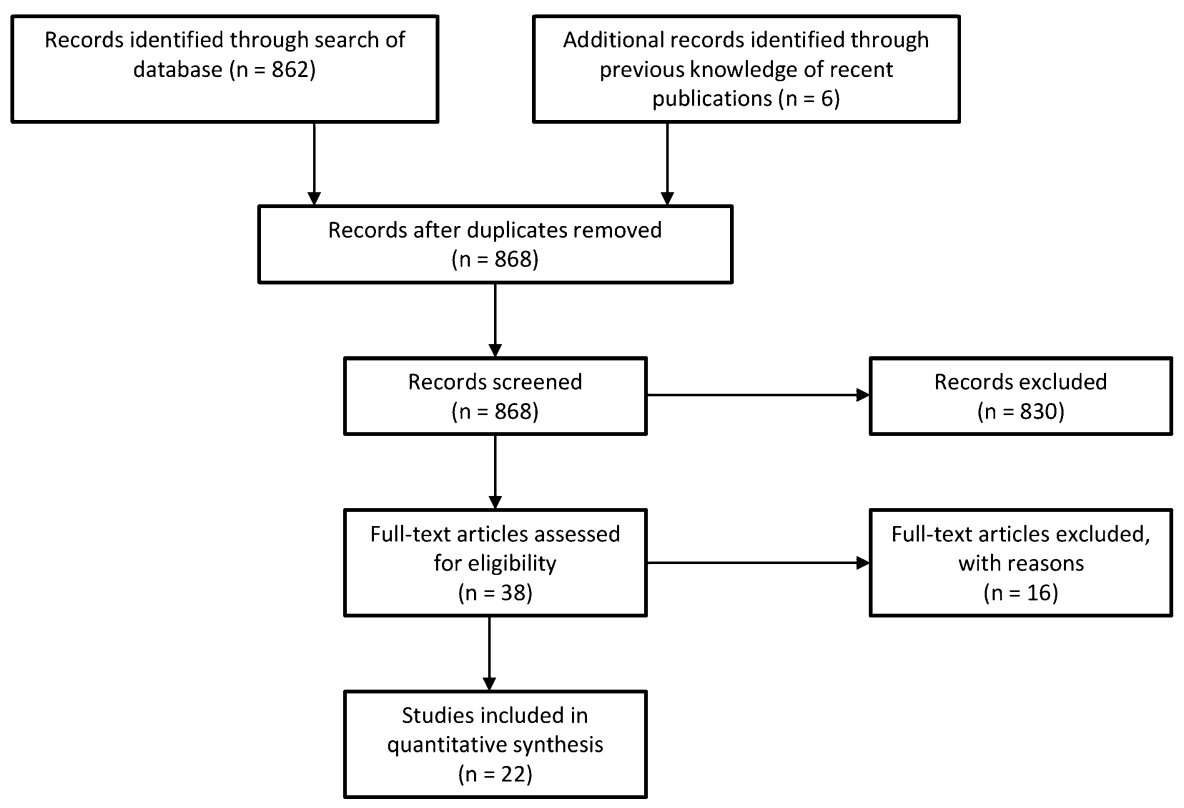

Fig. 1 Systematic screening process for eligibility of articles included in the review based on the PRISMA Flow Diagram (Moher et al. 2009)

forestry control contained 464 trees ha $^{-1}$ (Bambo et al. 2009 c). Individual tree growth was assumed to remain constant between silvopastures and open pastures.

Bird et al. (2010) included both open pasture and forested controls. Bark-free 6-m butt-log measurements were reported at year 25. Sheep liveweight gains $\mathrm{ha}^{-1}$ were extrapolated from the regression analysis in this study on a yearly basis for the first 25 years compared to the mean gains of the open pasture during the same time. Forage yields in the silvopasture were reported as a percentage of the open pasture forage yields in years 9-14.

Buergler et al. (2005) compared forage production under low-density tree plantings to medium- and highdensity plantings. The trees were young (7-8 years old) and so forage production under the low-density tree plantings was assumed to be equivalent to the production of an open pasture. A conventional nut orchard in this region is assumed to contain 245 trees $\mathrm{ha}^{-1}$ at a $1.8-\mathrm{m}$ and 3.7-m within- and between-row spacing, respectively. Based on tree spacing, the medium- and high-density plantings contained $61 \%$ and $27 \%$ fewer trees, respectively.

Burner and Brauer (2003) compared forages under three different tree spacings when the trees were 6-7 years old. When the trees were 14 years old, Burner et al. (2011) measured the volume of the same trees. The tree measurements within the respective silvopasture treatments were compared to the tree measurements collected from a 1.2-m and 2.4-m within- and between-row spacing plantation.

Clason (1999) did not directly compare forage yields in the silvopasture to an open pasture. However, the yields of Coastal bermudagrass (Cynodon dactylon cv. Coastal) were compared to forage yields of the same cultivar collected during the same time in similarly managed open pastures nearby (Eichhorn et al. 1983). Merchantable volume was compared between silvopasture and open pasture treatments when the stand was 31 years old.

Fannon et al. (2017) did not include an orchard comparison alone, but the spacing of these 13-14 year old trees resulted in an estimated 250 trees $\mathrm{ha}^{-1}$ stocking density, which would be similar to the stocking density of a conventional orchard planting.

Feldhake et al. (2008) harvested strips of forages at distinct points within alleyways $(12 \mathrm{~m}$ between tree rows). Because the tree canopy width was only $5 \mathrm{~m}$, the centermost harvest was considered the open pasture comparison for forage yields, whereas the silvopasture yield was considered the mean of all six harvest points within the alleyways. Total trees per hectare in the silvopasture layout was compared to the 
planting density within a conventional planting design with a 2.4-m between-row spacing.

Feldhake et al. (2010) measured forage production underneath a thinned hardwood forest. The level of thinning in this stand and thereby the subsequent tree basal area was assumed similar to what would have been completed in a typical timber thinning in this region. Forage production in the silvopasture two years following the establishment of the forages and soil amendment applications was compared to forage production in a nearby open pasture that had been managed as such for several decades.

Ford et al. (2017) compared cow and calf average daily gains (ADG) in open pastures and silvopastures which had been thinned from existing forest stands. The mean ADGs of cows and calves in each system were added for total ADG of all cattle in each pasture type. The basal area of trees within the silvopastures was compared to that of trees in comparable woodlands.

Kallenbach et al. (2006) did not compare timber production in the silvopastures to a control open pastures. For the purposes of this analysis, the silvopasture was assumed to have half of the number of trees in a plantation-style planting with $3-\times 3-\mathrm{m}$ spacing.

In the case of Kallenbach et al. (2010) the planting density of the trees was assumed to be the same as an orchard-style planting (Reid et al. 2009).

Karki et al. (2009) measured clover aboveground dry matter production in silvopastures and open pastures. The within- $(1.82-\mathrm{m})$ and between-row (3.04-m) spacings were assumed to be similar to the spacing utilized in a conventional plantation-style planting (South 2006). However, with 12.2-m wide alleyways, the silvopasture would only contain $60 \%$ of the trees of a pine plantation with this configuration.

Lewis et al. (1983) compared two grid-style planting configurations $(3.7-\times 3.7-\mathrm{m}$ and 6.1 $\times 6.1-\mathrm{m}$ spacings) of slash pine (Pinus elliotti Engelm.) in both a silvopasture and forest plantings. Wood yield was reported 20 years after planting. The total liveweight gains of cattle stocked on these silvopastures and open pastures was reported for years $5-19$. The mean yearly production of cattle over this period was multiplied by four and added to the sum of the latter 15 years of liveweight gains to account for the initial years of the silvopasture establishment phase.
McAdam and Hoppe (1997) compared lamb carrying capacity and liveweight gains in sycamore (Acer pseudoplatanus L.) silvopastures compared to open pastures. Because there were no differences in sheep carrying capacity between the systems, mean lamb growth was compared between all systems. Two types of silvopastures containing either 100 trees $^{h^{-1}}$ or 400 trees $\mathrm{ha}^{-1}$ were compared to a woodland control with 2500 trees $^{-1}$ (Sibbald and Daiziel 2000). No tree measures were reported so the stocking rate of trees per hectare was defined as tree productivity in this analysis.

Three years after applying soil amendments and establishing forage underneath a thinned hardwood forest, Neel and Belesky (2017) compared forage productivity in this silvopasture to forage productivity in an established nearby pasture that had been managed as such for several decades. The initial thinning was assumed to be comparable to a commercial thinning in a typical hardwood forest, and so the mean diameter at breast height was considered the productivity of the hardwood forest comparison. The diameter at breast height $\mathrm{ha}^{-1}$ following the final thinning one year prior to when forage and animal production were measured was considered the timber production of the silvopasture. Lamb stocking rates were adjusted based on forage availability in the pastures, but were not reported. Lamb production was calculated in this analysis as the product of the ADG of the lambs by the ratio of forage production in the silvopastures to the forage production in the open pastures.

Orefice et al. (2016) measured and compared forage productivity in silvopastures and open pastures after thinning or removing all the trees in a woodlot to develop the respective treatments. The authors considered the thinning of the forest for silvopasture similar in degree to a conventional thin for a managed woodlot.

Pent and Fike (2018) measured forage and lamb productivity in the same silvopastures as Fannon et al. (2017), but seven years later and after the trees had been thinned to 90 stems $\mathrm{ha}^{-1}$. This spacing was assumed in this analysis as comparable to a conventional, mature black walnut (Juglans nigra L.) or honeylocust orchard (Gleditsia triacanthos L.) (Reid et al. 2009). Lamb productivity for each system was reported as the ADG of the lambs multiplied by the stocking rate of each type of pasture. 
Sharrow et al. (1996) compared forage production in both open pastures, silvopastures, and timber plantations. Forages were only sown in the open pasture and silvopasture treatments, although forage production was reported for all three treatments. As a result, forage production in the silvopastures was compared to the sum of herbage production from both pastures and forest plantings. Two tree arrangements were compared, included grid-plantings and clusterplantings.

Teklehaimanot et al. (2002) reported the lamb carrying capacity and the growth rates of the lambs in several types of silvopastures and open pastures. The yield of the systems was considered the product of the carrying capacity and the growth rate (in $\mathrm{kg}$ ). In a similar way, the DBH of the trees and the trees hectare $^{-1}$ were reported. Thus, timber productivity was calculated in this analysis as the product of mean tree diameter in meters by the number of trees hectare $^{-1}$.

Results and synthesis of studies

These compiled studies report production characteristics from a wide variety of locations across the temperate regions of the globe, but the majority of the work in this analysis was collected within the United States (Fig. 2). The trees used in the studies were primarily coniferous. Comparisons of hardwood trees grown traditionally for timber were more common than comparisons of hardwood trees grown for nontimber forest products, such as nuts (e.g. black walnut) or pods (e.g. honeylocust). The forages in half of the studies consisted of perennial, cool season forage species. Systems utilizing annual forages were less common than pastures managed for perennial forage species. Sheep were the dominant livestock present in the comparisons that measured animal productivity.

Seven studies made direct, replicated comparisons between both open pasture productivity and forest productivity to productivity of forages or livestock and trees in silvopastures (Sharrow et al. 1996; Orefice et al. 2016; Ford et al. 2017; Bird et al. 2010; Clason 1999; Lewis et al. 1983; Teklehaimanot et al. 2002). The tree productivity estimates for two studies (Burner and Brauer 2003; McAdam and Hoppe 1997) came from additional publications of data collected on the same sites (Burner et al. 2011; Sibbald and Daiziel 2000). Three studies had no open pasture control. In

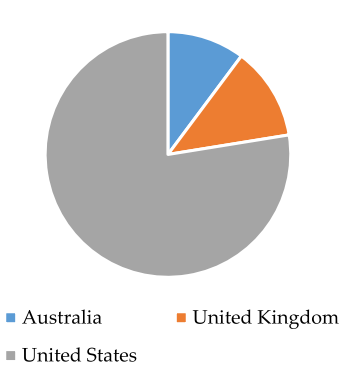

(a)

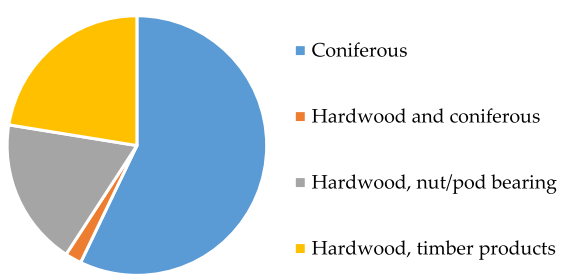

(c)

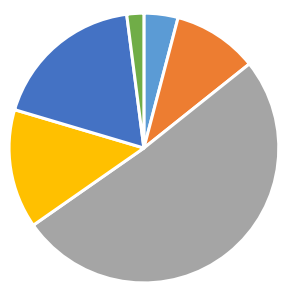

- Annual and perennial, cool-season

- Annual, cool-season

- Perennial, cool-season

- Perennial, warm- and cool-season

- Perennial, warm-season

- Perennial, warm-season and annual, cool-season

(d)

Fig. 2 Characteristics of compiled studies: a Countries where comparisons were made; $\mathbf{b}$ type of livestock in studies that reported animal performance in silvopasture and open pasture comparisons; $\mathbf{c}$ Type of trees in silvopasture and conventional silvicultural comparison; $\mathbf{d}$ type of forages in silvopasture and open pasture comparison

two cases, the middle of the alleyways in the silvopastures or low density plantings were far enough from trees such that a forage harvest at this location was considered the control (Feldhake et al. 2008; Buergler et al. 2005). In the other case, the author (Clason 1999) compared forage yield in the silvopasture to forage yields from a similar site (Eichhorn et al. 1983).

Tree productivity metrics were variable between studies (Table 2), and included measures of trees per unit of area (trees ha ${ }^{-1}$ ), volume production per unit of area $\left(\mathrm{m}^{3} \mathrm{ha}^{-1}\right)$, basal area per unit of area $\left(\mathrm{m}^{2} \mathrm{ha}^{-1}\right)$, diameter at breast height per unit of area $\left(\mathrm{m} \mathrm{ha}^{-1}\right)$, and predicted total biomass per unit of area $\left(\mathrm{kg} \mathrm{ha}^{-1}\right)$. 


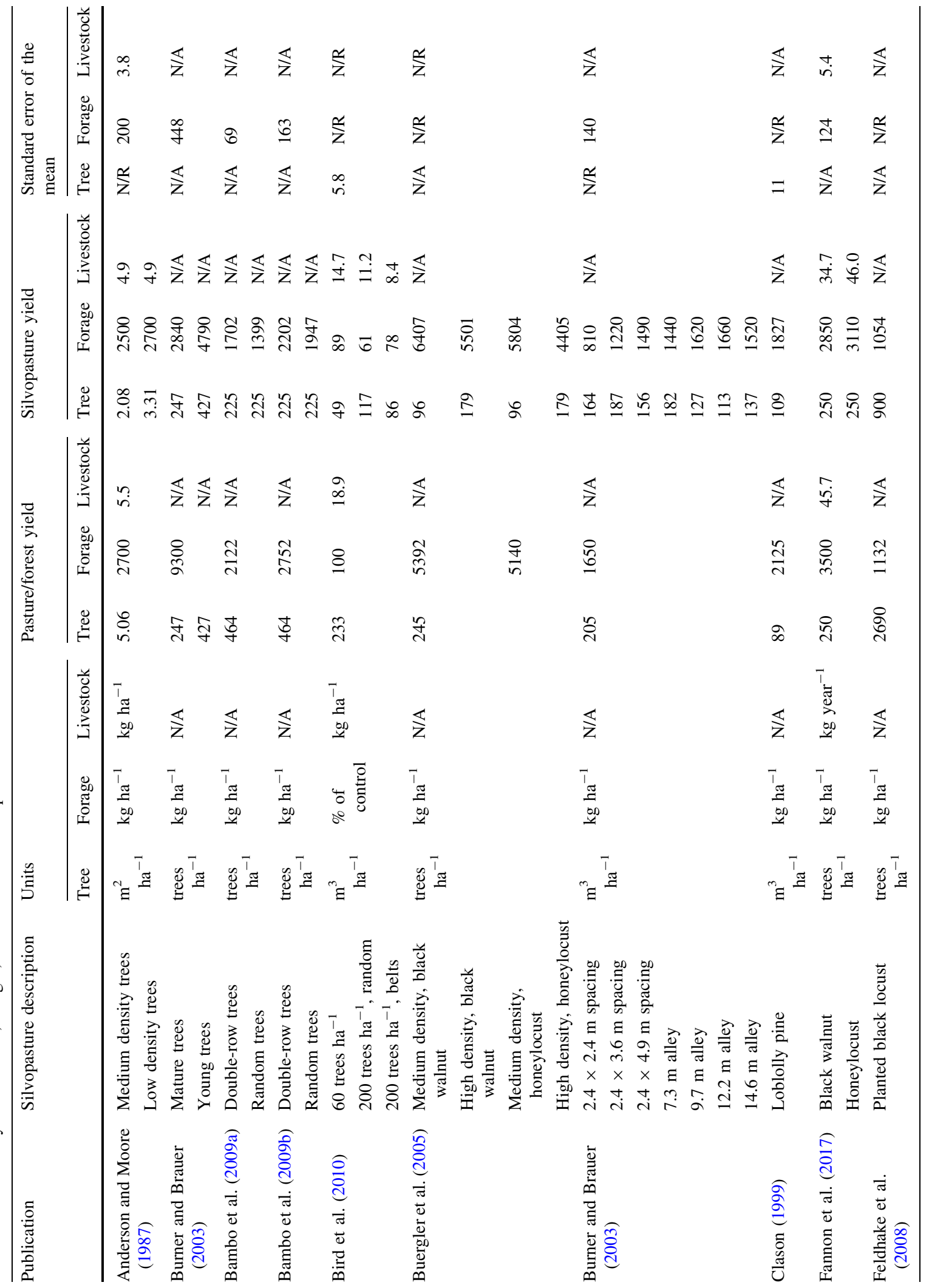




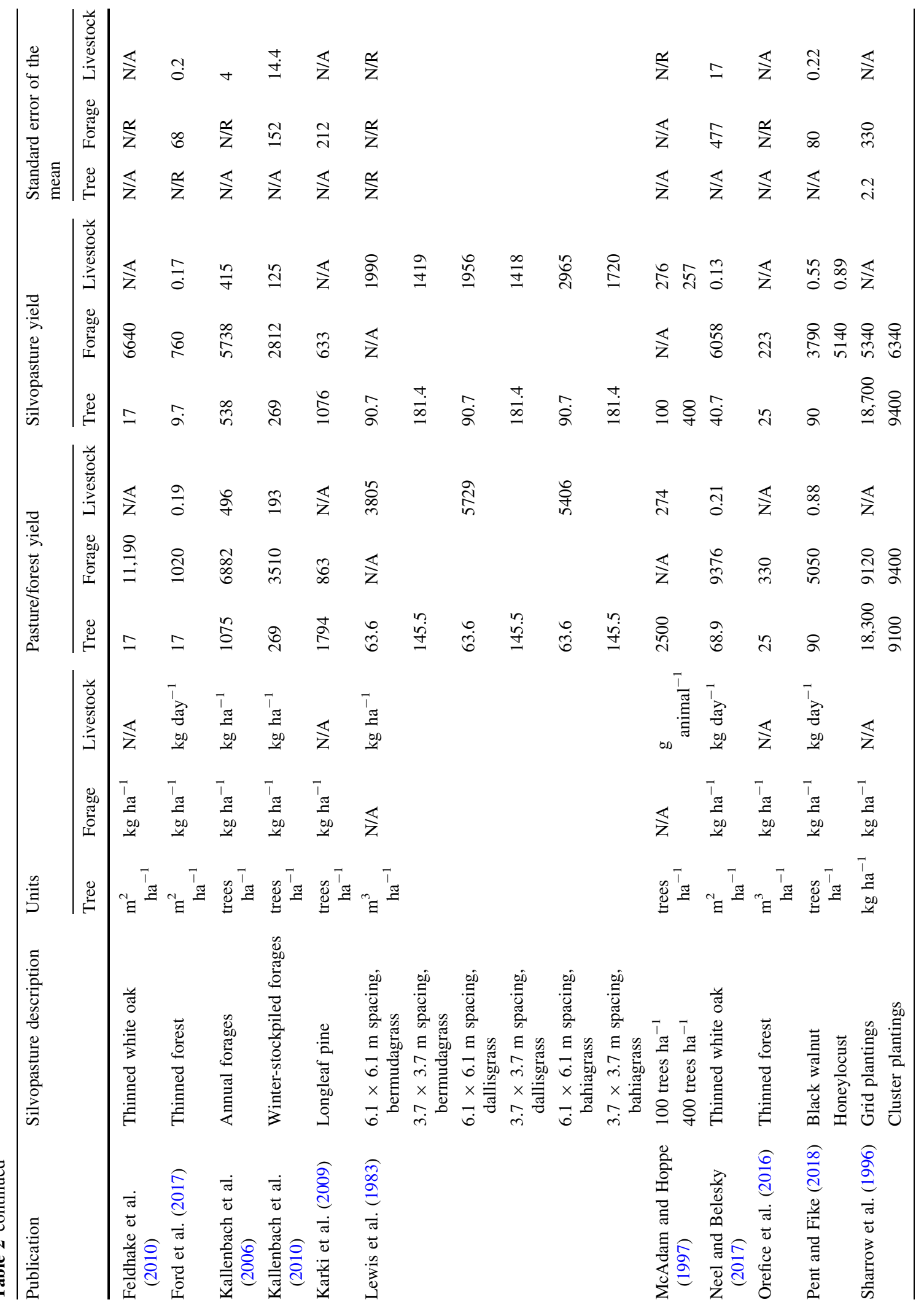




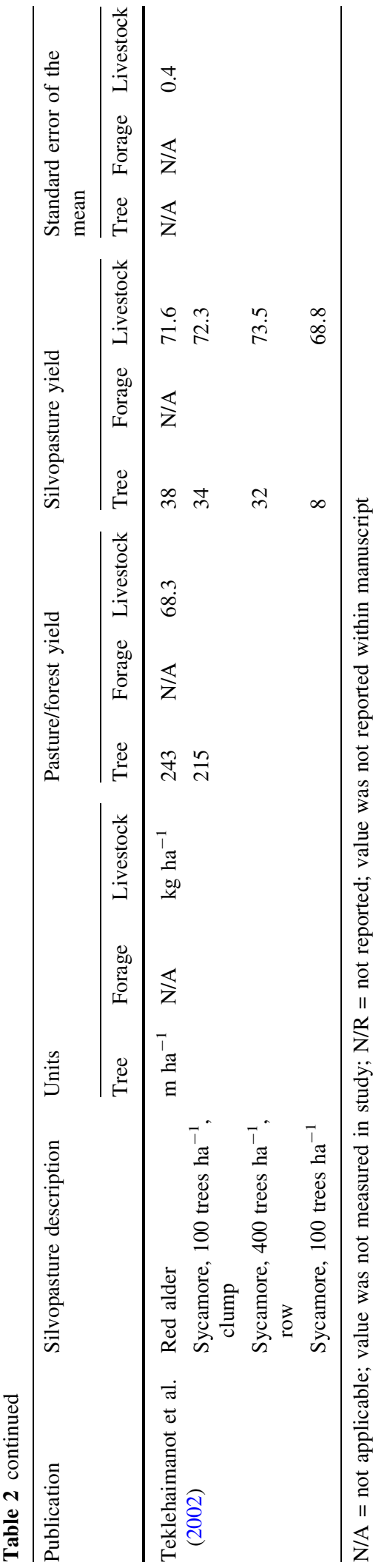

Forage productivity metrics were generally reported as total yield per unit of year $\left(\mathrm{kg} \mathrm{ha}^{-1}\right)$, although this may have been defined as either mean yield per cutting or per year. In one case, forage yield in the silvopasture was reported as a proportion of the yield in an open pasture (Bird et al. 2010). Livestock production was reported as liveweight gains of animal per unit of area, animal, year, or day, except in a single case where livestock production was reported as fleece weight per unit of area (Anderson and Moore 1987).

There were only two studies that reported that the yield of forages harvested from a silvopasture exceeded the yield of forages harvested from an open pasture (Pent and Fike 2018; Buergler et al. 2005). Several studies reported livestock productivity in some silvopastures to be greater than livestock productivity in open pastures, although these were marginal differences and in most cases were not reported as significantly different (Fannon et al. 2017; Pent and Fike 2018; McAdam and Hoppe 1997; Teklehaimanot et al. 2002). Three studies reported tree productivity in some silvopastures to be greater than tree productivity in control timber plantations (Sharrow et al. 1996; Clason 1999; Lewis et al. 1983).

All of the LERs based on forage and tree production exceeded one (Table 3). All but one study reported LERs based on animal and tree production that were greater than one. Within the anomalous study, two out of the three compared silvopasture systems were less productive than conventional systems where sheep and trees were managed separately (Bird et al. 2010). In several cases, the calculated LERs exceeded two (Fannon et al 2017; Pent and Fike 2018; Clason 1999).

The mean LER based on forage and tree production was $1.52(\mathrm{SE}=0.04)$, and the mean LER based on animal and tree production was $1.44(\mathrm{SE}=0.07)$. Based on this review, it would take around 0.71 ha of forest, timber plantation, or orchard plus 0.80 ha of pasture to equal the production from one hectare of silvopasture (Fig. 3). Similarly, one hectare of silvopasture would produce the same amount of livestock and silvicultural products as 0.74 ha of pasture and 0.70 ha of forest (Fig. 3). The distribution of LER values was greater when livestock production was used as the metric of open pasture productivity than when forage yield was used as the metric of open pasture productivity (Fig. 4). 


\section{Discussion}

Land productivity of silvopastures

As conventional agricultural systems strain to produce enough food, timber, and fiber to sustain a rapidly growing population in a sustainable manner (Tilman et al. 2011), the significantly greater production potential of temperate silvopasture practices warrants close consideration. The improved productivity of the silvopastures compared to conventional, segregated silvicultural and agricultural practices reported in this systematic review is similar to or better than the greater productivity observed in other intercropping practices, including both food-crop intercropping practices (Hiebsch and McCollum 1987; Ouma 2010; Aziz et al. 2015) and forage intercropping practices (Hiebsch and McCollum 1987). Based on the results of this review, silvopastures provide an opportunity to improve the productivity of land typically managed as pasture or forest alone by $42-55 \%$.

In addition, agroforestry practices, including silvopasture, are often cited as being more environmentally beneficial and culturally acceptable than alternative, conventional practices (Jose et al. 2019; Torralba et al. 2016). Improved resource utilization results in less nutrient loss from the pasture and therefore improvements in water quality (Boyer and Neel 2010; Michel et al. 2007). Silvopastures sequester more carbon than pastures or forests alone (Sharrow and Ismail 2004; Montagnini and Nair 2012). The beneficial buffering effect of trees on climatic extremes for livestock and forages is often considered a primary benefit of silvopastures by those who have adopted these practices (Orefice et al. 2017). The greater biodiversity within silvopastures is also appreciated by landowners and the general public (Lawrence et al. 1992). When coupled with greater productivity, the environmental and social sustainability of silvopasture practices makes these practices particularly appealing.

It is possible that this greater productivity will come at a cost of higher labor demands, managerial considerations, and inputs. These requirements are an important consideration for those interested in improving the productivity of their land. For example, trees in silvopastures may need to be pruned regularly to improve the value of the timber, while trees in traditional forest plantings may self-prune (Ares and
Brauer 2005). In addition, landowners familiar with silvopasture practices cite the uncertainty of global livestock and timber markets and the risk of long-term investments as concerns when considering silvopasture adoption (Shrestha et al. 2004). However, the inherent product diversity of silvopastures can have a stabilizing effect on farm income (Shrestha et al. 2004; Husak and Grado 2002). The cash flow of silvopastures is also much improved compared to forestry operations alone due to the annual returns of the livestock operation (Grado et al. 2001). Overall, silvopastures may be more or less profitable than conventional agricultural and silvicultural practices (Clason 1999; Husak and Grado 2002; Grado et al. 2001; Stainback and Alavalapati 2004; Bruck et al. 2019). It is clear that silvopasture practices are very productive, but the profitability of these practices will depend on the valuation of silvicultural and agricultural products and inputs required to successfully maintain these high levels of production.

Tree productivity in silvopastures

Coniferous trees were the most common of the types of trees used in these reviewed silvopasture practices. These trees are relatively fast growing, and thus conifer-based timber operations may be more productive than hardwood-based timber operations in some regions (Bruck et al. 2019). Coniferous trees may also be less sensitive to potential damage from the presence of grazing livestock (Sharrow et al 2009; Klopfenstein et al. 1997). Livestock will avoid browsing on conifers if alternative forages are available (Doescher et al. 1987). In some cases, coniferous trees may have more upright canopies that intercept less light than the canopies of hardwood trees (Sharrow et al. 2009).

Hardwood trees may be selected for a silvopasture over coniferous trees for a number of reasons including the production of valuable timber and non-timber forest products. Non-traditional products from trees, such as honeylocust pods, have considerable potential as a nutritious feed for livestock (Pent and Fike 2018; Johnson et al. 2013, 2012). Hardwoods may also be selected for a silvopasture because they are adapted or already present at a site (Ford et al. 2017; Orefice et al. 2017). When thinning a forest to create a silvopasture, the manager's ability to select trees is limited by the species of trees present in the stand, while the manager has more trees available for selection when planting 
Table 3 Land equivalency ratio (LER) in compiled studies when forage or livestock are considered as the metric of pasture productivity

\begin{tabular}{|c|c|c|c|}
\hline \multirow[t]{2}{*}{ Publication } & \multirow[t]{2}{*}{ Silvopasture description } & \multicolumn{2}{|c|}{ Silvopasture LER } \\
\hline & & Forage & Livestock \\
\hline \multirow[t]{2}{*}{ Anderson and Moore (1987) } & Medium density trees & 1.34 & 1.30 \\
\hline & Low density trees & 1.65 & 1.55 \\
\hline \multirow[t]{2}{*}{ Burner and Brauer (2003) } & Mature trees & 1.31 & N/A \\
\hline & Young trees & 1.52 & \\
\hline \multirow[t]{2}{*}{ Bambo et al. (2009a) } & Double-row trees & 1.29 & N/A \\
\hline & Random trees & 1.14 & \\
\hline \multirow[t]{2}{*}{ Bambo et al. (2009b) } & Double-row trees & 1.29 & N/A \\
\hline & Random trees & 1.19 & \\
\hline \multirow[t]{3}{*}{ Bird et al. (2010) } & 60 trees $\mathrm{ha}^{-1}$ & 1.10 & 0.99 \\
\hline & 200 trees $\mathrm{ha}^{-1}$, random & 1.11 & 1.09 \\
\hline & 200 trees $\mathrm{ha}^{-1}$, belts & 1.15 & 0.81 \\
\hline \multirow[t]{4}{*}{ Buergler et al. (2005) } & Medium density, black walnut & 1.58 & N/A \\
\hline & High density, black walnut & 1.75 & \\
\hline & Medium density, honeylocust & 1.52 & \\
\hline & High density, honeylocust & 1.59 & \\
\hline \multirow[t]{7}{*}{ Burner and Brauer (2003) } & $2.4 \times 2.4 \mathrm{~m}$ spacing & 1.29 & N/A \\
\hline & $2.4 \times 3.6 \mathrm{~m}$ spacing & 1.65 & \\
\hline & $2.4 \times 4.9 \mathrm{~m}$ spacing & 1.66 & \\
\hline & $7.3 \mathrm{~m}$ alley & 1.76 & \\
\hline & $9.7 \mathrm{~m}$ alley & 1.60 & \\
\hline & $12.2 \mathrm{~m}$ alley & 1.56 & \\
\hline & $14.6 \mathrm{~m}$ alley & 1.59 & \\
\hline Clason (1999) & Loblolly pine & 2.08 & N/A \\
\hline \multirow[t]{2}{*}{ Fannon et al. (2017) } & Black walnut & 1.81 & 1.76 \\
\hline & Honeylocust & 1.89 & 2.01 \\
\hline Feldhake et al. (2008) & Planted black locust & 1.27 & N/A \\
\hline Feldhake et al. (2010) & Thinned white oak & 1.59 & N/A \\
\hline Ford et al. (2017) & Thinned forest & 1.32 & 1.42 \\
\hline Kallenbach et al. (2006) & Annual forages & 1.33 & 1.34 \\
\hline Kallenbach et al. (2010) & Winter-stockpiled forages & 1.80 & 1.65 \\
\hline Karki et al. (2009) & Longleaf pine & 1.33 & N/A \\
\hline \multirow[t]{6}{*}{ Lewis et al. (1983) } & $6.1 \times 6.1 \mathrm{~m}$ spacing, bermudagrass & N/A & 1.95 \\
\hline & $3.7 \times 3.7 \mathrm{~m}$ spacing, bermudagrass & & 1.62 \\
\hline & $6.1 \times 6.1 \mathrm{~m}$ spacing, dallisgrass & & 1.77 \\
\hline & $3.7 \times 3.7 \mathrm{~m}$ spacing, dallisgrass & & 1.49 \\
\hline & $6.1 \times 6.1 \mathrm{~m}$ spacing, bahiagrass & & 1.97 \\
\hline & $3.7 \times 3.7 \mathrm{~m}$ spacing, bahiagrass & & 1.56 \\
\hline \multirow[t]{2}{*}{ McAdam and Hoppe (1997) } & 100 trees ha $^{-1}$ & N/A & 1.05 \\
\hline & 400 trees $\mathrm{ha}^{-1}$ & & 1.10 \\
\hline Neel and Belesky (2017) & Thinned white oak & 1.24 & 1.23 \\
\hline Orefice et al. (2016) & Thinned forest & 1.68 & N/A \\
\hline \multirow[t]{2}{*}{ Pent and Fike (2018) } & Black walnut & 1.75 & 1.63 \\
\hline & Honeylocust & 2.02 & 2.01 \\
\hline
\end{tabular}


Table 3 continued

\begin{tabular}{|c|c|c|c|}
\hline \multirow[t]{2}{*}{ Publication } & \multirow[t]{2}{*}{ Silvopasture description } & \multicolumn{2}{|c|}{ Silvopasture LER } \\
\hline & & Forage & Livestock \\
\hline \multirow[t]{2}{*}{ Sharrow et al. (1996) } & Grid plantings & 1.61 & N/A \\
\hline & Cluster plantings & 1.71 & \\
\hline \multirow[t]{4}{*}{ Teklehaimanot et al. (2002) } & Red alder & N/A & 1.21 \\
\hline & Sycamore, 100 trees $\mathrm{ha}^{-1}$, clump & & 1.22 \\
\hline & Sycamore, 400 trees $\mathrm{ha}^{-1}$, row & & 1.23 \\
\hline & Sycamore, 100 trees $\mathrm{ha}^{-1}$ & & 1.04 \\
\hline
\end{tabular}

N/A = not applicable; value was not measured in study

Fig. 3 Relative yield of silvicultural, agricultural, and total products from silvopastures compared to forests, timber plantations, or orchards and open pastures grown on the same amount of land; a Pasture production measured by forage yield; b Pasture production measured by livestock output. Error bars indicate standard error

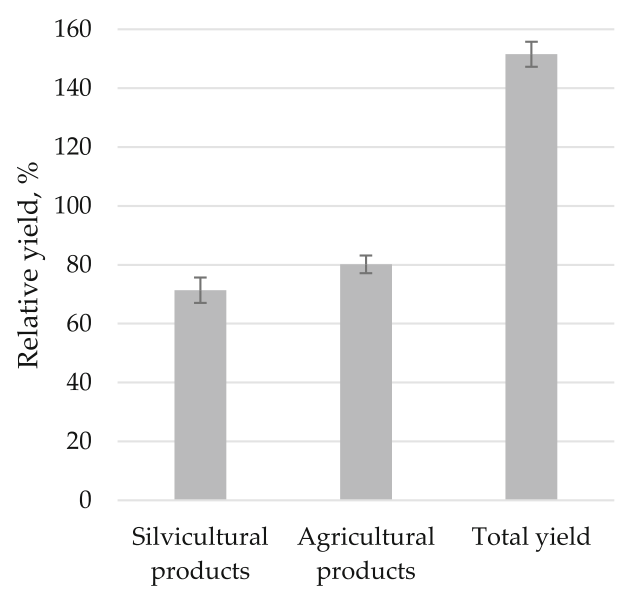

(a)

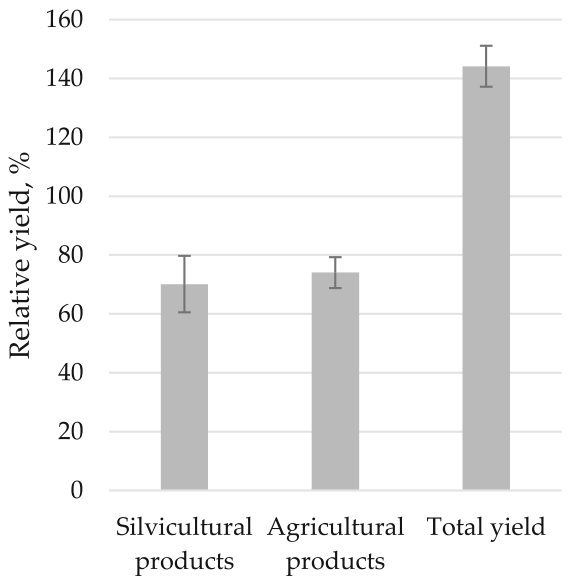

(b) trees into an existing pasture. In some areas, the traditional configuration of orchards may be conducive to forage establishment and livestock grazing during certain seasons of the year (Ares et al. 2006).

The productivity per unit area of land of the trees in the silvopasture was about $70 \%$ the productivity of trees managed in conventional silvicultural comparisons. This reduction was primarily a function of reductions in tree numbers in the silvopastures. Such reductions must often be made to permit enough light to reach the forage canopy for adequate growth. Comparisons of tree numbers rely on the assumption that individual tree growth is similar between practices. It would be more appropriate to compare tree productivity on a basis of volume produced per unit of land area or even basal area annual increment per unit of land area. Most studies did not report these figures.
This bias may be against the productivity of trees in the silvopastures or the conventional silvicultural practices depending on the context. The growth of individual pines in silvopastures has been shown to be greater than individual tree growth in timber-only plantations (Oswald et al 2017; Clason 1999). This may be a result of less competition between trees, vegetation suppression by grazing livestock, and nutrient additions or faster nutrient cycling in silvopastures. The duration and intensity of animal stocking management in a silvopasture will also have an effect on the growth of the trees (Pearson et al. 1990). For hardwood trees, height and diameter growth have been shown to be less when grown in a pasture than when grown free of competition with grass (Houx et al. 2012). In this case, forages were clipped and removed from the plots, which is not 
Fig. 4 Distribution of LER values from compiled silvopasture comparisons; a Pasture production measured by forage yield; b pasture production measured by livestock output

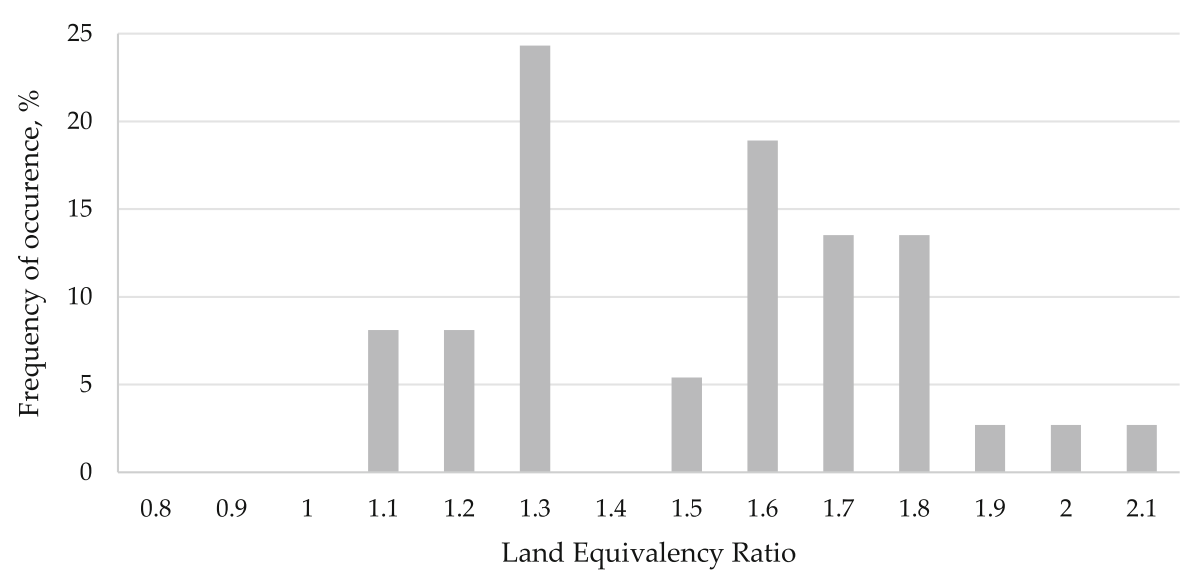

(a)

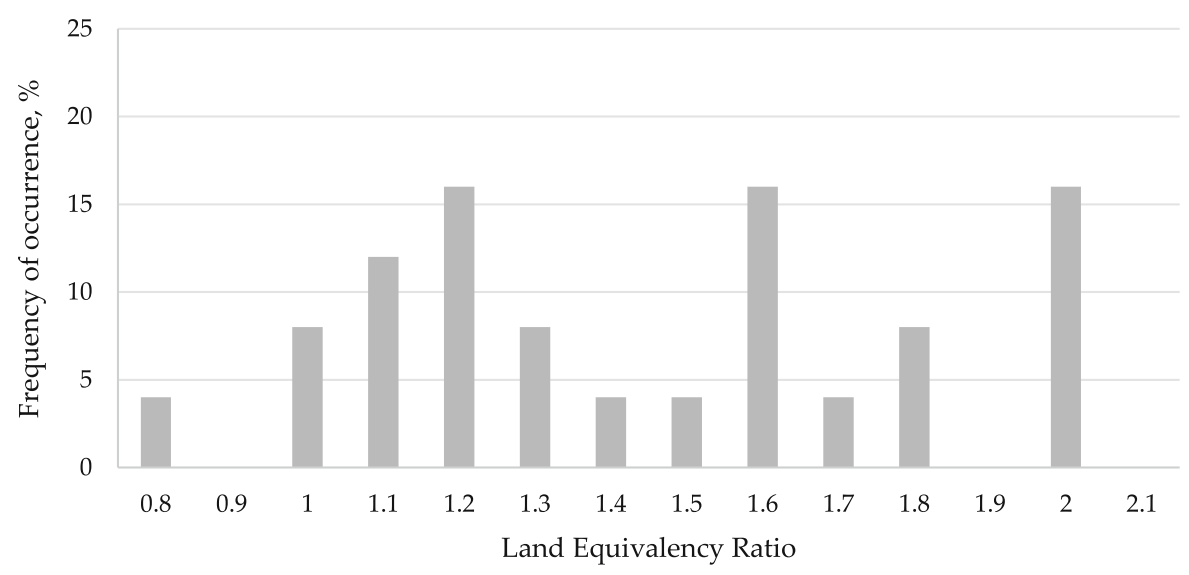

(b) representative of a typical silvopasture where the majority of nutrients harvested by livestock from the forages is returned to the soil for uptake by both forages and trees. Regarding production of nuts from trees, there is a lack of data available for individual trees in silvopastures as compared to trees in orchards.

\section{Forage productivity in silvopastures}

The photosynthetic pathway utilized by warm-season forages allows them to be more productive in warm environments than cool-season forages. Due to the differences in the mechanism of photosynthesis between warm- and cool-season plants, warm-season plants are able to utilize more light for growth. Coolseason grasses are often light-saturated at around 50\% of full sunlight (Hopkins 1999). Thus cool-season grasses may be just as productive under $50 \%$ shading as when exposed to full sunlight, compared to warmseason grasses which are much less productive in the shade than in full sunlight (Lin et al. 2001). Yields of cool-season forages may be less affected by the presence of trees in silvopastures than yields of warmseason forages (Brauer et al. 2004).

Cool-season grasses are more commonly grown in temperate regions because they are productive for a longer period of the year and are more suited to the cooler environment. The selection of forages for a silvopasture will often be dictated by the edaphic and climatic conditions of the site. However, trees will alter the microclimate of the silvopasture (Karki and Goodman 2015). In some situations, these differences may be enough to allow cool-season forages to persist in sites that are typically considered too warm for their production. 
The reduction in forage growth in silvopastures compared to open pastures was less than the reduction in tree productivity in the same sites. The land manager may presumably shift this balance towards tree production or forage production depending on which is more desirable. Over time as tree canopies close, forage production will decrease in silvopastures if the trees are not thinned or pruned (Lewis 1989; Bird et al. 2010).

Forage dry matter yields in a pasture are not the sole driver of animal performance, however. The nutritional value and the intake of the forage by the animal are of primary importance in determining the quality of a forage (Ball et al. 2001). Although outside the scope of this review, silvopastures do have an effect on forage nutritive value. Forages grown in silvopasture conditions in general have greater protein or nonprotein nitrogen levels and lower total non-structural carbohydrates (Kephart and Buxton 1993; Neel et al. 2008; Buergler et al. 2006).

\section{Livestock productivity in silvopastures}

Sheep are well suited to silvopastures for a number of reasons. Sheep will consume browse from woody shrubs or stump regrowth more readily than cattle (Doescher et al. 1987). Small ruminants also disturb and compact soils to a lesser degree than cattle (Betteridge et al. 1999). However, cattle are more prevalent than sheep in pasture production systems in the temperate regions of the globe (Bouwman et al. 2005). While sheep may be suited to silvopasture practices, there are opportunities to manage cattle effectively in silvopastures, as shown by some high, long-term production values reported in studies with cattle managed in silvopastures (Lewis et al. 1983). Small ruminants are easier and cheaper to manipulate, manage, and maintain in experimental studies. They consume much less forage than cattle on a per head basis, and so greater numbers of sheep may be managed than cattle within a designated experimental area. For these reasons, sheep may be utilized more frequently in experimental designs than cattle. However, sheep could be considered as a conservative model for cattle, as demonstrated by the slightly lower LER of studies with sheep in silvopastures compared to the LERS of studies of cattle in silvopastures.

In general, LERs were greater when forage yield was used as the metric of pasture productivity than when livestock production was used as the metric of productivity. The same trend was noted in the studies that reported both forage and animal production values. Forage characteristics as well as animal health and well-being are significant drivers of animal production. As mentioned previously, forage yield and nutritive value are both important in determining forage quality. Some studies have reported lower nutritive value of forages in silvopastures compared to open pastures, largely a function of reduced total nonstructural carbohydrate levels and greater concentration of fiber (Belesky 2005a, b; Neel et al. 2008; Buergler et al. 2006). Reductions in forage nutritive value in silvopastures may result in lower than expected levels of animal performance given the level of forage dry matter present in the pasture.

Animal performance, however, may also be influenced by the health and well-being of the animal. The cooler microclimate and reduced radiation in silvopastures can reduce core body temperatures of livestock compared to livestock without access to shade (Pent et al. 2018). This has been cited as a primary reason for why silvopasture practices are adopted on farms (Orefice et al. 2017). In the winter months, trees may also protect livestock from wind (Brandle et al. 2004). All of the comparisons in this review were evaluations of stocking livestock purely in silvopastures or in open pastures. In most cases, it will not be feasible or advisable to convert an entire farm to silvopasture. In a pasture rotation, silvopastures may prove to be of greatest benefit to animal welfare during certain seasons of the year. Determining in which seasons and conditions silvopastures will support the greatest level of animal performance will help farmers understand the potential value and function of silvopasture practices on their farms.

\section{Conclusions}

Comparing the productivity of silvopasture practices to the productivity of conventional agricultural and silvicultural practices indicates that silvopastures are $55 \%$ or $42 \%$ more productive than conventional practices, depending on whether the pasture productivity metric is forage yield or livestock output, respectively. When coupled with the environmental and social benefits of silvopastures, such levels of production have the potential to improve the 
sustainability of agricultural and silvicultural production practices. Profitability, however, depends on both productivity and necessary inputs, along with the market valuation of those products and inputs. Future work should focus on the financial implications for silvopasture given the high levels of productivity characteristic of these complex systems.

Open Access This article is licensed under a Creative Commons Attribution 4.0 International License, which permits use, sharing, adaptation, distribution and reproduction in any medium or format, as long as you give appropriate credit to the original author(s) and the source, provide a link to the Creative Commons licence, and indicate if changes were made. The images or other third party material in this article are included in the article's Creative Commons licence, unless indicated otherwise in a credit line to the material. If material is not included in the article's Creative Commons licence and your intended use is not permitted by statutory regulation or exceeds the permitted use, you will need to obtain permission directly from the copyright holder. To view a copy of this licence, visit http://creativecommons.org/licenses/by/4.0/.

\section{References}

Anderson GW, Moore RW (1987) Productivity in the first seven years of a Pinus radiata-annual pasture agroforest in Western Australia. Aust J Exp Agric 27:231-238

Angima SD, Green S, Reeb J (2010) Forage production and animal stocking rates in thinned Douglas-Fir forests. J Natl Assoc Cty Agric Agents 3

Ares A, Brauer D (2005) Aboveground biomass partitioning in loblolly pine silvopastoral stands: spatial configuration and pruning effects. For Ecol Mgmt 219:176-184

Ares A, Reid W, Brauer D (2006) Production and economics of native pecan silvopastures in central United States. Agrofor Syst 66:205-215

Aziz M, Mahmood A, Asif M, Ali A (2015) Wheat-based intercropping: a review. J Anim Plant Sci 25:896-907

Ball DM, Collins M, Lacefield GD, Martin NP, Mertens DA, Olson KE, Putnam DH, Undersander DJ, Wolf MW (2001) Understanding forage quality. American Farm Bureau Federation

Bambo SK, Blount AR, Nowak J et al (2009a) Annual coolseason forage nutritive value and production after overseeding into bahiagrass sod in silvopastoral systems. J Sustain Agric 33:917-934

Bambo SK, Blount AR, Nowak J et al (2009b) Effects of annual cool-season forage on bahiagrass production in silvopastures. J Sustain Agric 33:418-434

Bambo SK, Nowak J, Blount AR et al (2009c) Soil nitrate leaching in silvopastures compared with open pasture and pine plantation. J Environ Qual 38:1870-1878

Belesky DP (2005a) Growth of Dactylis glomerata along a light gradient in the central Appalachian region of the eastern USA: I. Dry matter production and partitioning. Agrofor Syst 65:81-90
Belesky DP (2005b) Growth of Dactylis glomerata along a light gradient in the central Appalachian region of the eastern USA: II. Mechanisms of leaf dry matter production. Agrofor Syst 65:91-98

Betteridge K, Mackay AD, Shepherd TG, Barker DJ, Budding PJ, Devantier BP, Costall DA (1999) Effect of cattle and sheep treading on surface configuration of a sedimentary hill soil. Soil Res 37:743-760

Bird PR, Kellas JD, Jackson TT, Kearney GA (2010) Pinus radiata and sheep production in silvopastoral systems at Carngham, Victoria, Australia. Agrofor Syst 78:203-216

Bouwman AF, Van der Hoek KW, Eickhout B, Soenario I (2005) Exploring changes in world ruminant production systems. Agric Syst 84:121-153

Boyer DG, Neel JPS (2010) Nitrate and fecal coliform concentration differences at the soil/bedrock interface in Appalachian silvopasture, pasture, and forest. Agrofor Syst 79:89-96. https://doi.org/10.1007/s10457-009-9272-4

Brandle JR, Hodges L, Zhou X (2004) Windbreaks in North American agricultural systems. Agrofor Syst 13:412-416

Brauer D, Burner D, Looper M (2004) Effects of tree configuration on the understory productivity of a loblolly pineforage agroforestry practice. In: Proceedings of the American Forage Grassland Council 412-416

Bruck SR, Bishaw B, Cushing TL, Cubbage FW (2019) Modeling the financial potential of silvopasture agroforestry in eastern North Carolina and Northeastern oregon. J For 117:13-20. https://doi.org/10.1093/jofore/ fvy065

Buergler AL, Fike JH, Burger JA et al (2005) Botanical composition and forage production in an emulated silvopasture. Agron J 97:1141-1147. https://doi.org/10.2134/ agronj2004.0308

Buergler AL, Fike JH, Burger JA et al (2006) Forage nutritive value in an emulated silvopasture. Agron J 98:1265-1273

Burner DM, Brauer DK (2003) Herbage response to spacing of loblolly pine trees in a minimal management silvopasture in southeastern USA. Agrofor Syst 57:69-77. https://doi. org/10.1023/A:1022943224478

Burner D, Dwyer J, Godsey L (2011) Stocking rate mediates responses of mid-rotation loblolly pine in west-central Arkansas. 1. Growth Agrofor Syst 81:287-293

Clason TR (1999) Silvopastoral practices sustain timber and forage production in commercial loblolly pine plantations of northwest Louisiana, USA. Agrofor Syst 44:293-303

DeBruyne SA, Feldhake CM, Burger JA, Fike JH (2011) Tree effects on forage growth and soil water in an Appalachian silvopasture. Agrofor Syst 83:189-200. https://doi.org/10. 1007/s10457-011-9376-5

Devkota NR, Kemp PD, Hodgson J et al (2009) Relationship between tree canopy height and the production of pasture species in a silvopastoral system based on alder trees. Agrofor Syst 76:363-374

Doescher PS, Tesch SD, Alejandro-Castro M (1987) Livestock grazing: a silvicultural tool for plantation establishment. J For 85:29-37

Eichhorn M, Nelson BD, Montgomery CR et al (1983) Yield and nutritive value of coastal, coastcross, alicia, and common bermudagrasses. Louisianna Agric Exp Stn 757:19 
Fannon AG, Fike JH, Greiner SP et al (2017) Hair sheep performance in a mid-stage deciduous Appalachian silvopasture. Agrofor Syst. https://doi.org/10.1007/s10457-0170154-X

Feldhake CM, Neel JPS, Belesky DP, Mathias EL (2005) Light measurement methods related to forage yield in a grazed northern conifer silvopasture in the Appalachian region of eastern USA. Agrofor Syst 65:231-239

Feldhake CM, Belesky DP, Mathias EL (2008) Forage production under and adjacent to Robinia pseudoacacia in Central Appalachia, West Virginia. In: Jose S, Gordon AM (ed) Toward agroforestry design: an ecological approach. Springer, Berlin, pp 55-66

Feldhake CM, Neel JPS, Belesky DP (2010) Establishment and production from thinned mature deciduous-forest silvopastures in Appalachia. Agrofor Syst 79:31-37

Fernandez-Nunez E, Rigueiro-Rodriguez A, Mosquera-Losada MR (2014) Silvopastoral systems established with Pinus radiata D. Don and Betula pubescens Ehrh.: tree growth, understorey biomass and vascular plant biodiversity. Forestry 87:512-524

Folkard PJ, Fraser LH, Carlyle CN, Tucker RE (2012) Forage production potential in a ponderosa pine stand: effects of tree spacing on rough fescue and understorey plants after 45 years. J Ecosyst Manag 13:1-14

Ford M, Zamora DS, Current D et al (2017) Impact of managed woodland grazing on forage quantity, quality and livestock performance: the potential for silvopasture in Central Minnesota, USA. Agrofor Syst 93:67-79

Grado SC, Hovermale CH, St. Louis CH (2001) A financial analysis of a silvopasture system in southern Mississippi. Agrofor Syst 53:313-322. https://doi.org/10.1023/A: 1013375426677

Hiebsch C, McCollum RE (1987) Area-X-time equivalency ratio: a method for evaluating the productivity of intercrops. Agron J 79:15-22

Hopkins WG (1999) Introduction to plant physiology, 2nd edn. Wiley, New York

Houx JH III, Mcgraw RL, Garrett HE et al (2012) Temperate silvopasture tree establishment and growth as influenced by forage species and cultural management practices. J Agric Sci 4:20-30

Husak AL, Grado SC (2002) Monetary benefits in a Southern silvopastoral system. South J Appl For 26:159-164. https:// doi.org/10.1093/sjaf/26.3.159

Johnson JW, Fike JH, Fike WB et al (2012) Millwood and wildtype honeylocust seedpod nutritive value changes over winter. Crop Sci 52:2807-2816. https://doi.org/10.2135/ cropsci2011.10.0542

Johnson JW, Fike JH, Fike WB et al (2013) Millwood honeylocust trees: seedpod nutritive value and yield characteristics. Agrofor Syst 87:849-856. https://doi.org/10.1007/ s10457-013-9601-5

Jose S, Walter D, Kumar BM (2019) Ecological considerations in sustainable silvopasture design and management. Agrofor Syst 93:317-331

Kallenbach RL, Kerley MS, Bishop-Hurley GJ (2006) Cumulative forage production, forage quality and livestock performance from an annual ryegrass and cereal rye mixture in a Pine Walnut Silvopasture. Agrofor Syst 66:43-53. https://doi.org/10.1007/s10457-005-6640-6
Kallenbach RL, Venable EB, Kerley MS, Bailey NJ (2010) Stockpiled tall fescue and livestock performance in an early stage midwest silvopasture system. Agrofor Syst 80:379-384. https://doi.org/10.1007/s10457-010-9322-y

Karki U, Goodman MS, Sladden SE (2009) Nitrogen source influences on forage and soil in young southern-pine silvopasture. Agric Ecosyst Environ 131:70-76

Karki U, Goodman MS (2015) Microclimatic differences between mature loblolly-pine silvopasture and open-pasture. Agrofor Syst 89:319-325. https://doi.org/10.1007/ s10457-014-9768-4

Kephart K, Buxton D (1993) Forage quality responses of C3 and C4 perennial grasses to shade. Crop Sci 33:831-837

Klopfenstein NB, Rietveld WJ, Carman RC et al (1997) Silvopasture: an agroforestry practice. USDA National Agroforestry Center, Washington

Lawrence JH, Hardesty LH, Chapman RC, Gill SJ (1992) Agroforestry practices of non-industrial private forest landowners in Washington State. Agrofor Syst 19:37-55

Lehmkuhler JW, Kerley MS, Garrett HE, Cutter BE (1999) Comparison of continuous and rotational silvopastoral systems for established walnut plantations in southwest Missouri, USA. Agrofor Syst 44:267-279

Lehmkuhler JW, Felton EED, Schmidt DA et al (2003) Tree protection methods during the silvopastoral-system establishment in midwestern USA: cattle performance and tree damage. Agrofor Syst 59:35-42

Lewis CE (1989) Herbage yield response to the maturation of a slash pine plantation. J Range Manag 42:191-195

Lewis CE, Burton GW, Monson WG, McCormick WC (1983) Integration of pines, pastures, and cattle in south Georgia. Agrofor Syst 1:277-297

Lin CH, Mcgraw RL, George MF, Garrett HE (2001) Nutritive quality and morphological development under partial shade of some forage species with agroforestry potential. Agrofor Syst 53:269-281

Lindgren PMF, Sullivan TP (2014) Response of forage yield and quality to thinning and fertilization of young forests: implications for silvopasture management. Can J For Res 44:281-289

Lindgren PMF, Sullivan TP, Ransome DB et al (2017) Longterm influence of stand thinning and repeated fertilization on forage production in young lodgepole pine forests. Can J For Res 47:1123-1130

Lopez-Diaz ML, Rigueiro-Rodriguez A, Mosquera-Losada MR (2009) Influence of pasture botanical composition and fertilization treatments on tree growth. For Ecol Manag 257:1363-1372

McAdam JH, Hoppe GM (1997) Sheep performance and production from a lowland silvopastoral system. Agrofor Forum 8:21-22

Michel G, Nair VD, Nair PKR (2007) Silvopasture for reducing phosphorus loss from subtropical sandy soils. Plant Soil 297:267-276. https://doi.org/10.1007/s11104-007-9352-z

Moher D, Liberati A, Tetzlaff J et al (2009) Preferred reporting items for systematic reviews and meta-analyses: the PRISMA statement. PLoS Med 6(7):e1000097

Montagnini F, Nair PKR (2012) Carbon sequestration: an underexploited environmental benefit of agroforestry systems. Agrofor Syst 61:281-295 
Morris DR, Clason TR (1997) Summer forage production under loblolly pine stands. Community Soil Sci Plant Anal 28:9-10

Neel JPS, Belesky DP (2017) Herbage production, nutritive value and animal productivity within hardwood silvopasture, open and mixed pasture systems in Appalachia, United States. Grass Forage Sci 72:137-153. https://doi. org/10.1111/gfs.12211

Neel JPS, Feldhake CM, Belesky DP (2008) Influence of solar radiation on the productivity and nutritive value of herbage of cool-season species of an understorey sward in a mature conifer woodland. Grass Forage Sci 63:38-47

Orefice J, Smith RG, Carroll J et al (2016) Forage productivity and profitability in newly-established open pasture, silvopasture, and thinned forest production systems. Agrofor Syst 93:51-65

Orefice J, Carroll J, Conroy D, Ketner L (2017) Silvopasture practices and perspectives in the Northeastern United States. Agrofor Syst 91:149-160. https://doi.org/10.1007/ s10457-016-9916-0

Oswald BP, Weng Y, Farrish KW et al (2017) A comparison of tree growth in loblolly pine (Pinus taeda) plantations and silvopasture settings in East Texas. For Res 6:1-2

Ouma G (2010) Sustainable horticultural crop production through intercropping: the case of fruits and vegetable crops: a review. Agric Biol J North Am 1:1098-1105

Pearson HA, Baldwin VC (1993) Agroforestry: southern pines and subterranean clover cultural treatments. Agrofor Syst 22:49-58

Pearson HA, Baldwin VC, Barnett JP (1990) Cattle grazing and pine survival and growth in subterranean clover pasture. Agrofor Syst 10:161-168. https://doi.org/10.1007/ BF00115364

Pent GJ, Fike JH (2018) Lamb productivity on stockpiled fescue in honeylocust and black walnut silvopastures. Agrofor Syst 93:113-121. https://doi.org/10.1007/s10457-0180264-0

Pent GJ, Fike JH, Kim I (2018) Ewe lamb vaginal temperatures in hardwood silvopastures. Agrofor Syst. https://doi.org/ 10.1007/s10457-018-0221-y

Perry MEL, Schacht WH, Ruark GA, Brandle JR (2009) Tree canopy effect on grass and grass/legume mixtures in eastern Nebraska. Agrofor Syst 77:23-35

Reid W, Coggeshall M, Garrett HE, Sambeek JV (2009) Growing black walnut for nut production. Agrofor Action 16:1-16

Robinson JL, Clason TR (2000) From a pasture to a silvopasture system. Agrofor Notes 22:1-4

Schroth G (1998) A review of belowground interactions in agroforestry, focusing on mechanisms and management options. Agrofor Syst 43:5-34
Sharrow SH, Carlson DH, Emmingham WH, Lavender D (1996) Productivity of two Douglas fir/subclover/sheep agroforests compared to pasture and forest monocultures. Agrofor Syst 34:305-313

Sharrow SH, Brauer D, Clason TR (2009) Silvopastoral practices. In: North American Agroforestry: an integrated science and practice, 2nd edn. Madison, pp 105-131

Sharrow SH, Ismail S (2004) Carbon and nitrogen storage in agroforests, tree plantations, and pastures in western Oregon, USA. Agrofor Syst 60:123-130. https://doi.org/10. 1023/B:AGFO.0000013267.87896.41

Shrestha RK, Alavalapati JRR, Kalmbacher RS (2004) Exploring the potential for silvopasture adoption in southcentral Florida: an application of SWOT-AHP method. Agric Syst 81:185-199. https://doi.org/10.1016/j.agsy. 2003.09.004

Sibbald AR, Daiziel RDM (2000) Silvopastoral national network experiment - annual report 1999. UK Agrofor Forum Newsl, vol 1, pp 2-6

Silva-Pando FJ, González-Hernández MP, Rozados-Lorenzo MJ (2002) Pasture production in a silvopastoral system in relation with microclimate variables in the atlantic coast of Spain. Agrofor Syst 56:203-211

South D (2006) Planting longleaf pine at wide spacings. Nativ Plants J 7:79-88

Stainback AG, Alavalapati JRR (2004) Restoring longleaf pine through silvopasture practices: an economic analysis. For Policy Econ 6:371-378. https://doi.org/10.1016/j.forpol. 2004.03.012

Teklehaimanot Z, Jones M, Sinclair FL (2002) Tree and livestock productivity in relation to tree planting configuration in a silvopastoral system in North Wales, UK. Agrofor Syst 56:47-55

Tilman D, Balzer C, Hill J, Befort BL (2011) Global food demand and the sustainable intensification of agriculture. Proc Natl Acad Sci 108:20260-20264

Torralba M, Fagerholm N, Burgess PJ et al (2016) Do European agroforestry systems enhance biodiversity and ecosystem services? A meta-analysis. Agric Ecosyst Environ 230:150-161. https://doi.org/10.1016/j.agee.2016.06.002

Vandermeer J (1981) The interference production principle: an ecological theory for agriculture. Bioscience 31:361-364

Workman SW, Bannister ME, Nair PKR (2003) Agroforestry potential in the southeastern United States: perceptions of landowners and extension professionals. Agrofor Syst 59:73-83

Publisher's Note Springer Nature remains neutral with regard to jurisdictional claims in published maps and institutional affiliations. 